\title{
The Nexus Between Export and Economic Growth in Tanzania
}

\author{
Dickson Utonga \\ MSc. Economics graduate - Mzumbe University
}

\section{Romanus L. Dimoso}

Senior Lecturer in Economics - Mzumbe University

\begin{abstract}
This study explored the causal relationship between exports and economic growth (GDP) in Tanzania. It analysed time series data for the period of 1980 to 2015. Economic growth, in this study, is measured in terms of growth per cent while exports are measured in percentage change of goods and services sold abroad. The purpose of this study was to examine the effectiveness of exports to economic growth in Tanzania. This was analysed by testing for the presence of unit root, co-integration and causality. The unit root test was performed and after the first difference data were stationary. Further, the Johansen co-integration and Granger causality tests were employed to examine the long-run relationship among variables. The results of co-integration indicate the existence of one co-integrating equation. The causality test results exhibited causality which runs from economic growth to exports. The results conclude that in the long run, production alone can cause exports growth. This means that export is not an effective stimulus to the economic growth of Tanzania. This study suggests that the Government should make efforts to enhance the production side or the supply side which is expected, in the long run, to develop trade and eventually the economy. The study, further, suggests that the government should take care of the import substitution industrialisation policies which encourage domestic production.
\end{abstract}

Keywords: Economic Growth, Exports, Co-integration, Granger Causality, Unit root

\section{Introduction}

It is argued that the role of international trade in influencing the economic growth of countries around the World has always been an issue of interest for academicians, economists and politicians (Dutt, Ghosh \& Austin 2015). Literally, economic growth is an important element for economic welfare in the World. With this view, exports as an important component of economic growth (GDP) is linked with economic growth. Exports of goods and services stand as the most important source of foreign currency for countries. Exports relieve pressure on the balance of payments and urgently contribute to creating employment opportunities. Economists link export trade with different levels of economic growth among countries. It is obvious that exports lead countries to intra-industry trade, integrate into the world economy and ease the pressure on external shocks for domestic economies (Abou-Stait, 2005). 
From the theoretical perspective, the classical economists i.e. Adam Smith and David Ricardo argued international trade as a key stimulus in boosting economic growth. In international trade, there emanate an important element 'exports' which stimulates economic growth. On the other hand, neoclassical economists highlight the importance of competitive advantage in international trade. A country can maximise its well-being through activities which are most efficient in resource and production. Relatively, the benefits of international trade are static which imply that trade liberation and openness cannot simply lead to an increase in long-run economic growth through exports. However, the most probable impact is claimed to happen in influencing income levels amongst nations. Further, external and domestic reasons that govern a country's export performance in the integration into the global economy are argued not to operate independently (WTO, 1996). A complex interaction exists both positively and negatively implying that a factor from one category can correctly interact with other factors in other categories. The developments in the external factors can lead to improving or worsening impacts of domestic factors and vice versa.

Export broadening is an influential agent to the successful development of developing economies since it creates a fundamental base for economic growth. Most of the least developed countries (LDCs) find that export diversification is a chimaera (Nicita, Shirotori \& Klok, 2013). Exports among LDCs are for large per cent concentrated in fewer sectors and are limited to primary commodities. Export indices concentration for LDCs has been rising since the last decade. In 2009, for example, the concentration of exports of LDCs was about four times as large as those of the developing economies (Nicita et al, 2013).

Although exports have been crucial for growth and development, developing countries are obscured by the challenge of expanding and diversifying export beyond their primary products. Through researches, it is well established that, trade openness and integration into global the markets have become important elements to successful strategies with sustained economic growth which are associated with export growth (Dollar \& Kraay, 2001). On top of that, the contribution of exports to economies of the developing countries is clearly subjected to a varied range of both empirical and theoretical perspectives. As a matter of fact, there have been various disagreements among scholars concerning the applicability and validity of export to economic development (Kaberuka, Rwakinanga, \& Tibesigwa, 2014).

For Tanzania, it is noted that under the period under which the Monthly Economic Review was undertaken i.e. in February 2015, the exports value of goods and services was approximated to USD $8,854.7$ million. The value is claimed to be $3.8 \%$ higher than the recorded amount in the corresponding period in 2014 (BOT, 2015). This expansion is evidenced to good performance in exports of both manufactured goods and travel receipts. Though the export sector shows to have been playing an important role in Tanzanian economic development, there is no much information which provides literature on the direct relationship between export and economic growth. From this perspective, this study is undertaken to objectively examine the relationship which typically exists between exports and economic growth in Tanzania. The application of exports and economic growth time series data for 54 years from 1980 to 2015 is carefully supplementing the study analysis. This study is orderly structured into main five sections: section one (1) presents both introduction and the background to the study, section two (2) presents synthesized information on literature review; section three (3) discusses data and methodology employed, section four (4) presents data presentation, analysis and discussion of the findings and section five (5) presents conclusion and recommendations which the study findings suggest. 


\section{Literature Review}

\subsection{The theoretical standpoint}

The export-led growth refers to a trade and economic policy initiative to foster the industrialisation process to facilitate the exportation of both goods and services. The goods under the export consideration are those with comparative advantages. It, further, requires the presence of market access mechanisms. This requirement arises due to the fact that some governments tend to sometimes aim at protecting infant industries. This action intends to provide an opportunity for small industries for growing and managing competition by comparative advantage. The prevalence of this situation, in reality, causes converse to occur. An example is on most of the East Asian countries which had strong barriers on imports around the 1960s - 1980s (Sanderatne, 2011).

In promoting exports, there are employment various stimulants such as a reduction in trade barriers such as tariff, floating the exchange rate basically by a devaluation of currencies. Apart from that, governments support the exporting sectors so as to promote export-led growth and, consequently, economic development. Essentially, the export-oriented industrialization was the stimulus of the improvement of the Asian economies such to mention are: Hong Kong, Taiwan, South Korea, and Singapore after World War II era (Sanderatne, 2011). Thus, it proves that export-led growth is a fundamental economic strategy which was adopted by some developing countries seeking to find a position in the world economy for their exported commodities. Industries producing such commodities could receive subsidies from their governments and get pace to better market access in both local and international levels. Success in the employment of this strategy, countries expects to generate foreign currency which is partly used to import more cheaply manufactured commodities from elsewhere around the World.

Despite the criticisms on the export-led growth strategy that it increases market sensitivity to exogenous factors, and being partially responsible for the damage of the 1997 Asian financial crisis, for lacking product diversity, and having limited success to economies with a decline in terms of trade, literature has proven that governments from East Asia had potentially the ability and resources in identifying and exploiting comparative advantages. Therefore, export-led growth has been highly supported as being a suitable development strategy for developing countries. This is due to its success in the Asian continent.

Therefore, despite the raised challenges on export-led growth, this may not be the case as such a strategy can successfully work in other developing countries. Thus, the notion from this theoretical view can capture on the case of Tanzania in ensuring that industrial base is strengthened in line with technological improvements. This will consequently help to access both domestic and foreign markets which generate income.

\subsection{Empirical review}

Empirical studies on examining the relationships between export and economic growth (GDP) can be categorised into two aspects. The first one being cross-sectional studies which seek to study the impact of exports on the economic growth of a specified group of countries, and the other being cross-country studies in which individual countries are investigated with the aim of studying the impact of export to the economic growth of the respective country.

\subsubsection{Cross-country studies}

This part covers the empirical analysis of studies conducted on seeking the relationship which exists between exports and economic growth among the group of countries in the World. This 
means that countries are investigated jointly to examine the working relationship. Some of the studies considered for this study are: -

Ee (2015) examined Export-Led Growth for the selected Sub-Saharan African (SSA) countries from 1985 to 2014. The approach used was a new generation panel data. The study findings showed the presence of cointegration. Moreover, there exists a long-run relationship between exports and economic growth. The estimation results showed that there is a positive impact of exports among other variables to SSA economic growth which proves that export-oriented growth strategy suit for the SSA countries.

Safdari and Mahmoodi (2011) explored the causal relationship between export and economic growth for 13 developing countries from 1988-2008, using panel VECM. There result depicted unidirectional reverse causality running from economic growth to exports.

Another study by Parida and Sahoo (2007) examined export-led growth hypothesis for developing countries from the Asian continents such as Pakistan, Bangladesh and Sri Lanka, using Padroni's panel cointegration technique. The results obeyed the validity of the export-led growth hypothesis. Cross-sectional studies conformed mixed behaviour of exports on economic growth.

Abu-Quarn and Abu-Bader (2004) on studying export and growth in the developing countries identified a positive relationship between these variables. In fact, there are more studies which suggest the presence of a positive long-run relationship between exports and GDP by using the causality test (Dodaro,1993., Sharma and Dhakal, 1994). On the other hand, with the use of cointegration techniques, other studies examine the long-run relationship between exports and GDP of specific countries; these are Oskooee and Alse (1994) and Oskooee and Economidou (2009). Moreover, causality is reported to run from either export trade to GDP or to both directions. These studies further suggest that causality applies in most of developing countries particularly in Africa.

\subsection{Specific country studies}

Apart from investigating the link between export and economic growth among groups of countries, the empirical literature is rich in studies which study the same to specific countries. The studies aimed at identifying the link so as to suggest important measures to strengthen the prevailing situation in both policies and strategies. These studies are, to explain some: -

On investigating the Costa Rica export-led growth hypothesis (Zehra, Nigar \& Taspinara, 2015) employed both the Johansen co-integration and Granger causality tests. This study aimed at examining the long-run relationship and the causality between export trade and economic growth. The results of Johansen co-integration indicated a long-run equilibrium relationship between exports and economic growth. The results from the Granger causality test showed a causality being unidirectional from the economic growth to export growth.

Ajmi, Aye, Balcilar \& Gupta (2013) conducted a study on investigating the dynamic causal linkage between exports and economic growth. The study used Granger causality tests on annual data for South Africa specifically on real exports and real GDP from the period 1911 to 2011. The test results showed no causality between exports and real GDP on the aspect of linear Granger causality test. On the contrary, the study of the same by using the nonlinear techniques to test for the Granger causality revealed the presence of bidirectional causality.

Kalaitzi (2013) conducted a study examining the nexus between exports and economic growth (GDP) in the United Arab Emirates (U.A.E.) from 1980 to 2010. In the study, the two-step EngleGranger co-integration test was applied together with the Johansen co-integration test to check 
for the existence of a long-run relationship among variables. In addition to that, the study employed a Vector Auto-regression (VAR) Model and Granger causality test to study the causality. The findings showed that a long-run relationship between manufactured and primary exports on economic growth exists. The Granger causality test depicted a unidirectional link between manufactured exports goods and economic growth. The study findings further suggested that an increase in the amount of export diversification from oil could result in the UAE's economic growth improvement.

On examining the relationship existing between real Exports, imports and economic growth (GDP) in Italy from 1863 to 2004, Pistoresi and Rinaldi (2012) employed the co-integration and causality tests. The existence of co-integration was confirmed by results from the analysis despite the direction of causality indicated to vary over time. The period pre-first World War, import led growth (GDP) turned into export-led growth (GDP). The causality observed was a bidirectional movement that was experienced after the period post-second World War.

By employing the co-integration and Granger causality analysis techniques from 1960-2003, Lorde (2011) probed the validity of export-led growth in Mexico. Empirically, the results indicated the existence of short-run relationship from export to economic growth. The study, further, identified inverse causation from economic growth to exports. This implies that economic growth (GDP) imposes significant effects on export for Mexico.

Kim and Lin (2009) studied the effect of export structure on economic growth (GDP). The study findings clearly showed that not exactly all exports components contribute equally to economic growth. This is particularly relevant to developing countries which largely depend on exports of their primary products which are affected by excessive price variabilities. Popularly, exports of the alike have minor impact on economic growth compared to industrial exports which had both a positive and significant effect on economic growth in that concern.

Abu (2006) scrutinised the export-led growth hypothesis in Jordan from the period 1976 to 1997. The empirical results of the study designated the existence of a unidirectional link from exports to output (GDP). The study findings maintained the Export-oriented growth strategy by the country. It argued that promoting economic growth more rapidly, government institutions like Free Zones Corporations, Jordan Investment Board (JIB) and Jordan Export Development Corporation (JEDC) had to continue chasing their missions to appealing foreign investments and boosting exports.

Therefore, specific country study analysis conceals variations on the impact of export-led growth. Furthermore, the studies on developing countries rest on the strong outcome of exports on economic growth (GDP) which suggest for countries to expand their level of exports for the long run economic prosperity. Purposefully, this study primarily targets to prove the validity of their suppositions in Tanzania.

\section{Data and Methodology}

\subsection{Data}

The data used for this investigation compose a time series for Tanzania covering from the period 1980 - 2015. The aggregated data, specifically for Tanzania, for this study include exports i.e. the volume of goods and services in percentage change and the economic growth in per cent as it is the indicator in measuring economic growth. Data were aggregated from the World Development Indicator (WDI) 2016 together with the International Financial Statistics department of the International Monetary Fund. 


\subsubsection{Economic growth}

For this study, economic growth is the per cent change in GDP and is regarded as the dependent variable denoted by GDP.

\subsubsection{Exports}

Exports values regarded in this study is denoted as EXP which captures goods and services in the model. It is regarded that export is a significant catalyst in improving the country's productivity. On the other hand, exports are believed to relieve economies of the foreign exchange constraint by allowing the importation of capital goods for boosting GDP. Therefore, a positive sign between exports and economic growth was expected in this study.

Export values are the current value of exports (f.o.b.) converted into U.S. dollars and expressed as a percentage of the average for the base period (2000). UNCTAD's export value indexes are reported for most economies. For selected economies for which UNCTAD does not publish data, the export value indexes are derived from export volume indexes (line 72) and corresponding unit value indexes of exports (line 74) in the IMF's International Financial Statistics

\subsection{Methodology}

Statistical descriptions for both economic growth and exports were clearly studied. The study employed the unit root test, causality existing among the two variables by using the Granger causality test so as to identify the directional causality between the variables of the study. Lastly, a long-run link was tested by using the Johansen cointegration test.

\subsection{Model Specification}

It is noted in the neoclassical trade theory that a country can gain from trade when its terms of trade are different from its own relative prices in autarky. It is further noted that a country having different Terms of Trade has chances for the production expansion in the factor abundant good. The trade theory can be evaluated in the neoclassical production function framework integrating exports into the production function. The Exports component is included in the function to address its association with economic growth. Thus, the improved production function can be specified as follows:

$$
\mathrm{Y}=\mathrm{F}(\mathrm{K}, \mathrm{EXP}, \mathrm{L})
$$

From this function, $\mathrm{Y}=$ economic growth (GDP), $\mathrm{K}$ stands for capital, $\mathrm{L}$ is the labour force, and EXP is the total amount of exports in goods and services. Being important in the production process, the economic theory appreciates that capital and labour effect GDP positively. Having positive externalities, the Export-Led Growth (ELG) hypothesis identifies that exports are expected to impose a positive effect on economic growth.

\section{Data presentation, analysis and discussion of the findings}

\subsection{Ordinary Least Square Technique}

The nexus between export and economic growth in Tanzania is firstly presented in the form of Ordinary Least Square (OLS) Technique. 
Table 4.1: Ordinary Least Square Results

\begin{tabular}{llllll}
\hline Variables & \multicolumn{4}{l}{ Dependent variable (GDP), Independent Variable (EXP) } \\
\hline \multirow{2}{*}{ EXP } & Coefficients & SE & t-ratio & $\mathrm{R}^{2}$ & F Statistic \\
\cline { 2 - 6 } & 0.0198724 & 0.0084639 & 2.35 & 0.1431 & 0.0250 \\
\hline \multirow{3}{*}{ GDP } & Dependent variable (EXP), Independent Variable (GDP) \\
\cline { 2 - 6 } & Coefficients & SE & t-ratio & $\mathrm{R}^{2}$ & F Statistic \\
\hline
\end{tabular}

Null Hypothesis (Ho): There is no relationship between the study variables

Alternative Hypothesis (H1): There is a relationship between the variables

As the OLS results are clearly summarized in table 4.1; The results reject the Null hypothesis which claimed that there exists no significant relationship between variables under investigation. Through the empirical analysis of results, it is proposed that there is a positive relationship between export and economic growth and vice versa. This allows for the analysis of the relationship to be investigated further.

\subsection{Stationarity of the study variables}

Variables were individually analysed to identify their respective stationarity properties by using the Augmented Dickey-Fuller (ADF) tests. This implies that the presence of unit root in the study variables was examined. This is for the reason that the Johansen cointegration and Granger causality tests require the econometric methodology to be stationary.

The ADF test makes adjustments of the Dickey-Fuller (DF) test to cater for the possibility of serial correlation in the disturbance terms by adding the lagged difference terms of the dependent variable. Therefore, the presence of a unit root in the variables of the study was tested both in their raw form and first differences as shown in Table 4.1

Table: 4.1. Results of the Augmented Dickey-Fuller (ADF) test

\section{Full Period (1980-2015)}

\begin{tabular}{lll}
\hline & \multicolumn{2}{c}{ Variables in Levels: Critical Values $(-3.682$ for $1 \%$ and -2.972 for $5 \%)$} \\
\cline { 2 - 3 } & GDP & EXP \\
\cline { 2 - 3 } TEST & -2.627 & $-4.443^{*}$ \\
& 1st Differences: Critical Values $(-3.689$ for $1 \%$ and -2.975 for $5 \%)$ \\
& GDP & EXP \\
ADF & $-10.352^{*}$ & $-8.160^{*}$ \\
TEST & & \\
\hline
\end{tabular}

* and ** denote that the test statistic is significant at the 1 and 5 per cent levels of significance, respectively. By using different methods such as LR, FPE, HQIC, AIC and SBIC a lag length of 1 was chosen for ADF tests in order to obtain white-noise residuals. 
From table 4.1 using ADF tests, shows that one of the variables (EXP) alone represents stationarity process the variable is integrated of order 0 i.e. $I(0)$. The other variable (GDP) was not stationary but it was stationary after the first difference at 1 per cent level of significance and the variable is integrated of order 1 i.e. $I$ (1).

From the ADF each time series ( GDP and EXP) were stationary at the $1 \%$ level meaning that they were stationary at the of order one $\mathrm{I}(1)$ and $\mathrm{I}(0)$ respectively. This was according to the selection criteria of which two lags were selected. The fact is that all variables were stationary after the first difference at $1 \%$ level of significance. Therefore, the next move followed, which essentially necessitates that the two-time series variables must be co-integrated.

\subsection{Co-integration test}

Suppose there are $\mathrm{n}$-dimensional time series variables $\mathrm{yt}$ is said to be cointegrated if some linear combination $\beta_{1 y} 1 \mathrm{t}+\ldots+\beta_{\mathrm{nynt}}$ of the component variables becomes stationary. This combination is called a cointegrating relation and its coefficients $\beta=\left(\beta_{1}, \ldots, \beta_{\mathrm{n}}\right)$ compose a cointegrating vector.

Cointegration implies that despite the fact that being individually not stationary, the linear combination of the two-time series data can be stationary. Gujarati and Sangeetha (2010) argued that the integration of two-time series variables in the model suggests the presence of a long run or equilibrium relationship between them. Granger (1986) noted that a test for cointegration can be used as a pre-test to get out of a spurious regression situation.

Rank is the key feature in Johansen's value. This is equal to the number of independent cointegrating equations in the model. Then the series will be tested for cointegration, suppose the tests rectify its presence, then an Error Correction Model (ECM) will be constructed, and later a parsimonious model of the series will also be developed.

The long-run relationship among variables can be estimated by using the Johansen cointegration test. It is relying on the vector autoregressive (VAR) models.

Table 4.2 Tests for co-integration using Johansen test

\section{Full period model (1980-2015)}

\begin{tabular}{llll}
\hline Eigen Values & $\cdot$ & 0.45101 & 0.08438 \\
Hypotheses & $r=0$ & $r \leq 1$ & $r \leq 2$ \\
T Statistic & 21.3226 & $2.7326^{*}$ & \\
\hline
\end{tabular}

From this table (4.2), $\mathrm{r}$ is the hypothesized number of cointegrating vectors *and ${ }^{* *}$ denote rejection of the hypothesis at 5 per cent and 1 per cent of significance. Trace statistic indicates the presence of cointegration at the 0.05 level since the trace statistic is less than the critical value rank.

Therefore, the results in table 4.2. shows that Trace statistic value is above $5 \%$ critical value, hence it rejects the null hypothesis of no cointegration at $r \leq 1$. Thus the results, suggest that there does exist cointegrating (long-run) relationship between economic growth (GDP) and per cent changes in exports (EXP).

\subsection{Granger Causality Test}

Causality refers to a concept which is used in building the forecasting models. Granger 
causality test is a technique which is used in determining whether one-time series is significant in forecasting another (Granger, 1969). In general, the standard Granger causality test pursues to determine whether previous values of a variable predicts changes in another. The following table 4.3 presents the results obtained from the test

Table: 4.3 Result for Granger Causality Test

\begin{tabular}{lccc}
\hline \multicolumn{4}{c}{ Granger Causality Tests for Full Period (1980-2015) } \\
\hline Null Hypothesis: (Lags 4) & Obs & Chi-square & Probability \\
GDP does not Granger Cause EXP & 32 & 21.672 & 0.000 \\
EXP does not Granger Cause GDP & 32 & .95772 & 0.916
\end{tabular}

H0: EXP $\neq$ EXPG (EXP does not Granger cause GDP)

$\mathrm{H}_{1}$ : GDP $\neq$ EXP (GDP does not Granger cause EXP)

\section{Interpretation}

The results of the Granger Causality Test have presented in table 4.3 The results imply that economic growth (GDP) Granger cause exports while export does not Granger cause economic growth. Therefore, results show that the causality is unidirectional (i.e causality runs in one direction).

\section{Conclusion and Recommendations}

The validity of the export to influencing economic growth has so many perspectives. This paper clearly identifies the relationship between exports trade and economic growth (GDP GROWTH) in Tanzania. The use of time series data from 1980 to 2015 was considered.

A number of econometric methodologies which offer various techniques were applied in investigating the causality relationship between Export trade growth and economic growth.

In the Tanzania case, the study reveals that the long-run relationship exists as it has been confirmed by the co-integration test which confirms the existence of cointegration between exports rates and GDP growth rates. The results are in line with Lorde (2011) who probed the validity of export-led growth in Mexico.

Empirically, the results identified inverse causation from economic growth to exports. This implies that economic growth (GDP) imposes significant effects on export for Mexico.

With the use of the Granger Causality test, it is evidenced that there exists unidirectional causality from GDP growth rates to exports rates. This concurs with the results of (Zehra, et al, 2015) whose Granger causality test showed a causality being unidirectional from the economic growth to export growth. It is viable for Tanzania to make efforts to strengthen her level of GDP since it is an ingredient to attaining impacts on the export level. Tanzania can still adopt the export-led industrialisation which will boost domestic production and consumption and consequently bring about impacts to export and the country as a whole.

Therefore, it is worthwhile for Tanzania to make efforts in strengthening the level of economic growth (GDP). GDP is a very important ingredient to improve the export capacity of countries. Tanzania can still implement the export-led industrialisation which can boost both domestic production and consumption and ultimately increase exports which generate income. It is now the matter of reviewing and restructuring policies and strategies which can successfully help to strengthen the level of exports which is considered as one of the most important factors in determining economic development among developing countries. 


\section{References}

About-Stait, F. (2005), Are exports the Engine of Economic Growth? An Application of Cointegration and Causality Analysis for Egypt, 1977-2003. Economic Research Working.

Abu Al- Foul, B. (2004), Testing the export-led growth hypothesis: Evidence from Jordan, Applied Economics Letters, No. 11, pp. 393-396.

Abu-Qarn, A. S., \& Abu-Bader, S. (2004). The validity of the ELG hypothesis in the MENA region: Cointegration and error correction model analysis. Applied Economics, 36(15), 1685-1695.

Ahdi N. Ajmi \& Goodness C. Aye \& Mehmet Balcilar \& Rangan Gupta, (2013). Causality between exports and Economic Growth in South Africa: Evidence from Linear and Nonlinear Tests, Working Papers 201339, University of Pretoria, Department of Economics.

Ahdi N. Ajmi \& Goodness C. Aye \& Mehmet Balcilar \& Rangan Gupta,( 2013). Causality between Exports and Economic Growth in South Africa: Evidence from Linear and Nonlinear Tests, Working Papers 201339, University of Pretoria, Department of Economics.

Bahmani-Oskoee, M. \& Alse, J., (1994). Export Growth and Economic Growth: an application of cointegration and error-correctionmodelling. The Journal of Developing Areas 27, 53542.

Bahmani-Oskooee, \& M., Economidou, C., (2009). Export-led growth vs. growth led to Exports: LDCs experience. The Journal of Developing Areas 42 (2), 179-209.

Bahmani-Oskooee, M. and Economidou, C. (2009). Export-led growth vs. growth led to Exports: LDCs experience. The Journal of Developing Areas, 42(2), 179-212.

Bbaale E, \& Mutenyo J., 2011. Export composition and economic growth in Sub-Saharan Africa: a panel analysis. Consilience: The Journal of Sustainable Development. 6(1): 1-19.

Dodaro, S., 1993. "Exports and growth: A reconsideration of causality", Journal Developing Areas, , Vol. 27, pp.227-44.

Dutt, S. D., Ghosh, D., \& Austin, A. (2015). Export Growth-economic Growth Nexus: An Empirical Re-examination. Journal of Business and Economics JBE, 6(12), 1999-2007.

Ee, C. Y. (2016). Export-led Growth Hypothesis: Empirical Evidence from Selected Sub-Saharan African Countries. Procedia Economics and Finance, 35, 232-240.

Gokmenoglu, K. K., Sehnaz, Z., \& Taspinar, N. (2015). The Export-Led Growth: A Case Study of Costa Rica. Procedia Economics and Finance, 25, 471-477.

Gujrati. N Damoder \& Sangeetha (2010). Basic Econometrics. (4th ed.). New York, Tata McGraw Hill (Chapter 21).

Kaberuka, W., Rwakinanga, E. T., \& Tibesigwa, W. (2014). Is Export-led-growth hypothesis valid in Uganda? A cointegration and causality analysis (1960-2010). Journal issues. Issues in Business Management and Economics Vol.2 (4), pp. 060-073.

Kalaitzi, A. (2013). Exports and Economic Growth in the United Arab Emirates. Submitted to: RIBM Doctoral Symposium. Manchester Metropolitan University, Business School.

Kalaitzi. A., (2013). Exports and Economic Growth in the United Arab Emirates. Submitted to: RIBM Doctoral Symposium. Manchester Metropolitan University Business School. 
Kim, D. H. \& Lin, S. C. (2009). Trade and Growth at Different Stages of Economic Development, Journal of Development Studies, Vol. 45, No. 8, pp. 1211-1224.

Kraay, A., \& Dollar, D. (2001). Trade, Growth, and Poverty. Policy Research Working Papers.

Lorde, T. (2011). Export-led Growth: A Case Study of Mexico. International Journal of Business, Humanities and Technology, 33-44.

Mohsen Bahmani-Oskooee \& Janardhanan Alse, 1994. "Short-Run versus Long-Run Effects of Devaluation: Error-Correction Modeling and Cointegration," Eastern Economic Journal, Eastern Economic Association, vol. 20(4), pages 453-464, Fall.

Mwinuka, L., \& Mlay, F. (2015). Determinants and Performance of Sugar Export in Tanzania. Journal of Finance and Economics, 3(1), 6-14.

Nicita, A, Miho S, \& TuBolormaa, M. (2013). "Survival analysis of the Exports of least developed countries: The role of comparative advantage". United Nations conference on trade and development policy. Issues in international trade and commodities study. Series No. 54

Paper, No. 76, Tunis: African Development Bank.

Parida, P. C., \& Sahoo, P. (2007). Export-led Growth in South Asia: A Panel Cointegration Analysis. International Economic Journal, 21(2), 155-175.

Pistoresi, B., \& Rinaldi, A. (2012). Exports, imports and growth. Explorations in Economic History, 49(2), 241-254.

Safdari, M., Mahmoodi, M., \& Mahmoodi, E. (2011). The Causality Relationship between Export and Economic Growth in Asian Developing Countries. American Journal of Scientific Research, (25), 40-45.

Sharma, S. C., \& Dhakal, D. (1994). Causal Analysis between Exports and economic growth in developing countries. Applied Economics, 26, 1145-1157.

Tanzania, Bank of Tanzania. (2015). Monthly Economic Review. 